International Journal of Life Sciences
Available online at www.sciencescholar.us
Vol. 4 No. 1 April 2020, pages: 19-25
e-ISSN: 2550-6986, p-ISSN: 2550-6994
https://doi.org/10.29332/ijls.v4n1.373

\title{
The Effect of Giving Betel Leaf Extract (Piper Betel L.) on the Production and Quality of Broiler Carcasses
}

\begin{tabular}{l} 
Ermelia Maria F. R. Lodang a, Gusti Ayu Mayani Kristina Dewi b, I Made Nuriyasa c \\
Manuscript submitted: 27 November 2019 Manuscript revised: 09 December 2019, Accepted for publication: 18 January 2020 \\
\hline Corresponding Author c
\end{tabular}

International Journal of Life Sciences (C) 2020.

This is an open access article under the CC BY-NC-ND license (https://creativecommons.org/licenses/by-nc-nd/4.0/).

\footnotetext{
Contents

Abstract

a Udayana University, Denpasar, Indonesia

b Udayana University, Denpasar, Indonesia

c Udayana University, Denpasar, Indonesia
}

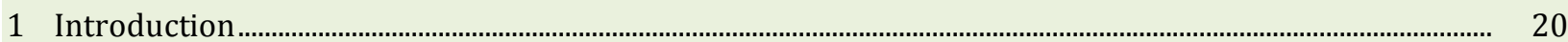

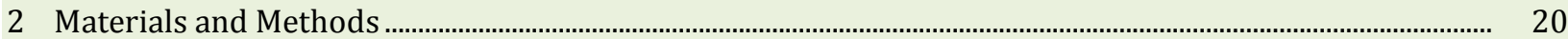

3 Results and Discussions ....................................................................................................................................... 21

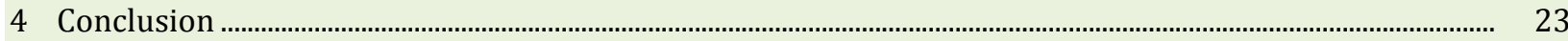

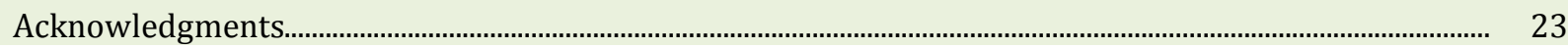




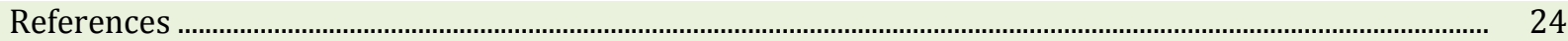

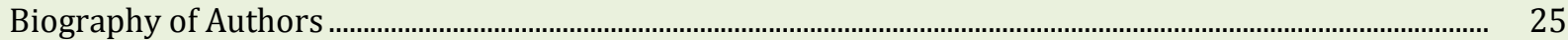

\section{Introduction}

The broiler is livestock that has the rapid growth of meat in a relatively short time. Broiler meat is very popular in society in addition to the highly nutritious food, also the price is cheaper than other meat products. The production of broiler in Indonesia has increased annually as the population increases. Broiler as a contributor to the largest livestock products, about $73.11 \%$ of all poultry populations in Indonesia in the year 2018. Growing livestock products are causing an increased use of drugs, especially antibiotic synthesis to increase production and prevention of disease in chickens.

Use of antibiotics as a growth factor or Antibiotic Growth Promoters (AGPs), administered through feed in small quantities or sub-therapeutic levels and in the long term. However, the use of AGPs can interfere with human health as consumers, due to the presence of antibiotic residue in foodstuffs and the emergence of zoonotic bacterial strains that are resistant to antibiotics. This is detrimental because it lowers the effectiveness of antibiotic therapy used in the treatment of various infections in humans as consumers (Dahiya et al., 2006). Since January 1, 2006, the European Union prohibits the use of antibiotics as a growth factor in livestock products. The main consequences of banning the use of AGPs include decreased production and increased disease necrotic enteritis in poultry.

The medicinal compounds that enter the body of cattle cannot be entirely excreted from the tissues and will be restrained in the body tissues as residues. Rahayu (2014), states that residues can be found due to the use of drugs, including antibiotics, feeding additive or hormonal growth-boosting hormones. With regard to the need for broiler meat that is low cholesterol and adequate nutrient. One alternative to increase chicken production and still provide a safe breeding product for consumption is by utilizing herbal plants as an antibiotic or natural medicines in the livestock industry. Haroen (2014), expressed the use of citrus juice waste flour up to $5 \%$ in rations can increase the weight of the cut, the weight of carcasses and reduce the cholesterol of carcasses and abdominal fat. The same is also conveyed by Suriani (2018), that the administration of Temulawak extract of $0.5 \mathrm{~g}$ per liter of drinking water and the administration of turmeric extract of $0.25 \mathrm{~g}$ per liter of drinking water is able to produce the same meat production as broiler chickens that are given vitamins and synthetic antibiotics.

Another herbal plant that is potential as a natural antibiotic is betel leaf. According to the Sholikhah (2006), phytochemical compounds contained in the betel leaf are alkaloids, saponin, tannins, essential oils, and flavonoids. Plants containing flavonoids compounds can be used as anticancer, antioxidant, antiinflammatory, anti-corruption, and antihypertensive. The important role of flavonoids from betel leaf is to reduce the risk of developing heart disease and stroke (Fauziah, 2010). According to Hardiyansyah (2016), that the feeding of the addition of betel leaf flour (Piper betle L.) to level 1\% able to lower cholesterol broiler meat and the lowest cholesterol levels obtained in the provision of betel leaf flour level $1 \%$ with cholesterol levels $14 \mathrm{mg} / \mathrm{dl}$. Based on this, researchers want to identify phytochemical compounds of betel leaf water (Piper betle L) and apply its use to quantity and quality of broiler meat production.

\section{Materials and Methods}

Chicken

Broiler chickens used were 2 weeks old as many as 90 chickens.

Cage Research

The cages used by the battery colony system were 30 plots. The cage material used is BRC wire. Each plot is 40 $\mathrm{cm}$ wide, $50 \mathrm{~cm}$ long and $50 \mathrm{~cm}$ high. 
Rations and drinking water

Rations and drinking water will be provided on an adlibitum basis. With an arrangement consisting of yellow corn, fish meal, rice bran, coconut cake, and coconut oil. The drinking water provided is water with a mixture of betel leaf water extract at the level of $2 \%$ and $4 \%$.

\section{Research variable}

Ration consumption: ration consumption will be measured once a week. The given ration is reduced by the remaining ration. Drinking water consumption: drinking water consumption will be measured every day using a measuring cup. Initial weight: initial weight is measured before the chicken is put in the treatment cage. Final body weight: Final body weight is calculated after the chicken is harvested. Dry matter digestibility protein digestibility, and energy digestibility. Weight gain is measured by the final weight minus the initial weight. Feed Convention Ratio (FCR): is a comparison between the amount of ration consumption and weight gain in the same period.

Bacteria in broiler cecum

Percentage of carcass parts consisting of carcass weight, carcass percentage, meat percentage, fat percentage, bone weight, and Meat Bone Ratio.

\section{Data analysis}

The data obtained were analyzed by analysis of variance and if there were significant differences (P < 0.05$)$ between treatments, then continued with the multiple distance test from Duncan (Steel and Torrie, 1993).

\section{Results and Discussions}

The results of the study in table 1 showed that the consumption of ration and consumption of drinking water in each treatment showed results of no real effect $(\mathrm{P}>0.05)$. This is because the provision of rations in all three treatments is the same so that the nutritional needs of chickens are fulfilled with the rations given. This is in line with the opinion of Bidura et al. (2017), that the administration of herbal extracts (leaves and garlic) as much as $5 \mathrm{cc} / 100 \mathrm{cc}$ of drinking water has no real effect on the consumption of rations and drinking water. Wibawa et al. (2016), also reported that the administration of herbal extracts of plants (garlic) through drinking water at a concentration of $2.5-5 \%$ has no real effect on the consumption of rations and drinking water.

The value of Feed Conversion Ratio (FCR) shows no apparent difference ( $>0.05$ ) is because the treatment has no real effect on ration consumption and weight gain so that the conversion of ration shows no distinct results. The initial weight and weight of the broiler's end of the chicken showed no distinct results (P > 0.05). This is due to the uniformity in terms of maintenance such as the chicken grouping of the same amount, the provision of rations with the same nutrient levels and the same environmental conditions as temperature.

Table 1

Effect of leaf water extract of Siriht (Piper Betle L.) through drinking water against broiler performance

\begin{tabular}{lllll}
\hline \multirow{2}{*}{ Variable } & \multicolumn{3}{c}{ Treatments $^{1)}$} & \multirow{2}{*}{ SEM $^{2)}$} \\
\cline { 2 - 4 } & $\mathrm{A}$ & $\mathrm{B}$ & $\mathrm{C}$ & 14,11 \\
Ration Consumption (kg/tail) & $1373,2^{\mathrm{a}}$ & $1369,9^{\mathrm{a}}$ & $1365,5^{\mathrm{a}}$ & 23,31 \\
Drinking Water Consumption (L/tail) & $1732,2^{\mathrm{a}}$ & $1756,8^{\mathrm{a}}$ & $1772,5^{\mathrm{a}}$ & 0,05 \\
Feed Convertion Ratio (FCR) & $1,50^{\mathrm{a}}$ & $1,46^{\mathrm{a}}$ & $1,41^{\mathrm{a}}$ & 33,67 \\
Weight Gain (kg/tail) & $925,80^{\mathrm{a}}$ & $942,75^{\mathrm{a}}$ & $984,50^{\mathrm{a}}$ & 8,75 \\
Initial Weight (g/tail) & $668^{\mathrm{a}}$ & $666,65^{\mathrm{a}}$ & $667,75^{\mathrm{a}}$ & 34,02 \\
Final Weight (kg/tail) & $1593,8^{\mathrm{a}}$ & $1609,4^{\mathrm{a}}$ & $1652,25^{\mathrm{a}}$ & 3 \\
\hline
\end{tabular}

Lodang, E. M. F. R., Dewi, G. A. M. K., \& Nuriyasa, I. M. (2020). The effect of giving betel leaf extract (piper betel l.) on the production and quality of broiler carcasses. International Journal of Life Sciences, 4(1), 19-25. https://doi.org/10.29332/ijls.v4n1.373 
Description:

1) The provision of drinking water without the addition of betel leaf extract as A control (A), the provision of drinking water with the addition of $2 \%$ betel leaf extract (B), and the provision of drinking water with the addition of $4 \%$ betel leaf extract (C).

2) SEM: "Standard Error of the Treatment Means"

The results of the study in table 2 show that the weight of the carcass in treatment $\mathrm{A}$ and $\mathrm{C}$ shows $\mathrm{A}$ different real result $(\mathrm{P}<0.05)$. It is suspected because the effectiveness of the compounds contained in the betel leaf as an antioxidant, antiseptic, natural and antibacterial antibiotic, causing maximum nutrient absorption will cause the efficiency of the ration also maximal so that it will affect the weight of carcasses.

Percentage of carcasses, percent of meat, fat and skin percentages, the weight of bones and weight of meat in the study showed no real difference in results (P > 0.05). Haroen (2003), states that the percentage of carcasses is closely related to weight loss and weight gain. It is also likely to cause because the fodder used in this study has the same protein and energy balance. Energy is required for all life activities and the production of meat so that lack of energy can lead to stunted growth (Fadillah et al., 2007; Mardewi et al., 2017). In addition, protein-energy is also very influential for the percentage of carcasses because it is necessary for the growth and formation and repair of tissues (Tillman et al., 1991), so that it will affect the weight of carcass and weight, and will also affect the percentage of carcasses.

Table 2

The effect of leaf water extract of Siriht (Piper Betle L.) through drinking water against the percentage of broiler carcasses

\begin{tabular}{lllll}
\hline \multirow{2}{*}{ Variable } & \multicolumn{3}{c}{ Treatments $^{1)}$} & \multirow{2}{*}{ SEM $^{2)}$} \\
\cline { 2 - 4 } & A & B & C & 18,73 \\
Carcass Weight (kg/tail) & $1120,5^{\mathrm{a}}$ & $1161,8^{\mathrm{ab}}$ & $1193^{\mathrm{b}}$ & 1,97 \\
Percentage of Carcass (\%) & $70,69^{\mathrm{a}}$ & $72,28^{\mathrm{a}}$ & $72,64^{\mathrm{a}}$ & 1,05 \\
Meat Percentage (\%) & $53,15^{\mathrm{a}}$ & $53,35^{\mathrm{a}}$ & $54,01^{\mathrm{a}}$ & 1,19 \\
Percentage of Fat and Skin (\%) & $15,51^{\mathrm{a}}$ & $15,27^{\mathrm{a}}$ & $14,94^{\mathrm{a}}$ & 10,36 \\
Bone Weight (g) & $234,80^{\mathrm{a}}$ & $222,20^{\mathrm{a}}$ & $216,90^{\mathrm{a}}$ & 19,28 \\
Meat Weight (g) & $594,2^{\mathrm{a}}$ & $619,9^{\mathrm{a}}$ & $625,1^{\mathrm{a}}$ & 0,12 \\
Meat Bone Ratio & $2,54^{\mathrm{a}}$ & $2,88^{\mathrm{a}}$ & $3,00^{\mathrm{a}}$ & 0 \\
\hline
\end{tabular}

Description:

1) The provision of drinking water without the addition of betel leaf extract as A control (A), the provision of drinking water with the addition of $2 \%$ betel leaf extract (B), and the provision of drinking water with the addition of $4 \%$ betel leaf extract (C).

2) SEM: "Standard Error of the Treatment Means"

Table 3

The influence of betel leaf water extract (Piper Betle L.) through drinking water to the digestibility of dry materials, protein digestibility and energy digestibility of broiler

\begin{tabular}{lllll}
\hline \multirow{2}{*}{ Variable } & \multicolumn{3}{l}{ Treatments $^{1)}$} \\
\cline { 2 - 4 } & $\mathrm{A}$ & $\mathrm{B}$ & $\mathrm{C}$ & \\
\hline Dry Matter Digestibility (\%) & $81,55^{\mathrm{a}}$ & $82,31^{\mathrm{a}}$ & $82,46^{\mathrm{a}}$ & 1.02 \\
Protein Digestibility (\%) & $71,98^{\mathrm{a}}$ & $74,47^{\mathrm{a}}$ & $75,11^{\mathrm{a}}$ & 1,47 \\
Energy Digestibility (\%) & $72,49^{\mathrm{a}}$ & $72,60^{\mathrm{a}}$ & $72,77^{\mathrm{a}}$ & 0,28 \\
Total Plate Count (CFU/gram) & $1,88 \times 10^{6 \mathrm{a}}$ & $1,12 \times 10^{6 \mathrm{ab}}$ & $9,5 \times 10^{5 \mathrm{~b}}$ & 75,19 \\
Collyform (CFU/gram) & $1,77 \times 10^{6 \mathrm{a}}$ & $9,7 \times 10^{5 \mathrm{a}}$ & $7,3 \times 10^{5 \mathrm{~b}}$ & 52,37 \\
E. Colly (CFU/gram) & $3,7 \times 10^{5 \mathrm{a}}$ & $2,05 \times 10^{5 \mathrm{~b}}$ & $1,60 \times 10^{5 \mathrm{~b}}$ & 53,34 \\
\hline
\end{tabular}


Description:

1) The provision of drinking water without the addition of betel leaf extract as A control (A), the provision of drinking water with the addition of $2 \%$ betel leaf extract (B), and the provision of drinking water with the addition of $4 \%$ betel leaf extract (C).

2) SEM: "Standard Error of the Treatment Means"

The results of Table 3 study showed that the administration of betel leaf extract did not have any real effect (P $>0.05$ ) to the digestibility of dried ration materials, protein digestibility, and energy digestibility. According to Anggorodi (1994), High low feed digestibility is influenced by ambient temperature, the pace of feed travel through the digestive device, the physical form of feed material, the composition of rations, and the influence on the comparison of Zatother foods. In line with the Abun (2005), the high low digestibility of foodstuffs in rations can be influenced by the pace of the travel ration in the gastrointestinal tract, as well as the nutritional content contained in the ration. According to Sitepu et al. (2002), the higher the digestibility value of dried ration material illustrates that the quality is good so it is easy to digest the body.

The results of the research on the use of betel leaf extract against Total Plate Count (TPC) are distinct (P. < 0.05). The research results in the number of Coliforms shows that the $A$ and $B$ treatments are not distinct $(\mathrm{P}>$ 0.05 ) but $A$ distinct real treatment $(P<0.05)$ against the $C$ treatment using the addition of $4 \%$ betel leaf extract in drinking water. The results of the research on the number of $\mathrm{E}$. Coly indicate A distinct real treatment $(\mathrm{P}<0.05)$ to the treatment of $\mathrm{B}$ and $\mathrm{C}$ that uses $2-4 \%$ of betel leaf extract through drinking water. This is due to the substance content contained in betel leaf extract can suppress the growth of microorganisms in the gastrointestinal tract broiler. Compound phenol propanoic is antimicrobial and anti-fungal strong and can inhibit the growth of some types of bacteria, among others, Salmonella sp, Klebsiella, Pasteurella, and can turn off Candida albicans (Reveny, 2011). The essential oil of betel leaf is generally active against Escherichia coli, Posiodomonas auruginosa, Strepto coccos epidermidis, Staphylococcus aureus and Streptococcus pyrogen (Arambewela et al., 2005).

\section{Conclusion}

The introduction of betel leaf water level $4 \%$ can increase carcass weight and decrease the number of bacteria in the broiler.

\section{Acknowledgments}

The authors want to thank the Indonesian Government through the research and public departments. Thanks also to Universitas Udayana, rector of Udayana. Dean and Udayana Livestock Sciences.

Lodang, E. M. F. R., Dewi, G. A. M. K., \& Nuriyasa, I. M. (2020). The effect of giving betel leaf extract (piper betel l.) on the production and quality of broiler carcasses. International Journal of Life Sciences, 4(1), 19-25. https://doi.org/10.29332/ijls.v4n1.373 


\section{References}

Abun. (2005). The effect of fermentation of tuber pulp (Maranta Arundinacea L.) with the Cardamos of Aspergilus Niger Terhaap value of broiler Ransum. Scientific articles. Faculty of Livestock, University of Padjajaran. Bandung.

Anggarodi. (1994). General Livestock Food Science. PT. Jakarta.

Arambewela, L. S. R., Arawwawala, L. D. A. M., \& Ratnasooriya, W. D. (2005). Antinociceptive Activities of Aqueous and Ethanol Extracts of Piper betle. Leaves in Rats. Pharmaceutical biology, 43(9), 766-772. https://doi.org/10.1080/13880200500406545

Bidura, I. G. N. G., Partama, I. B. G., Putri, B. R. T., \& Watiniasih, N. L. (2017). Effect of water extract of two leaves (Allium sativum and Sauropus androgynus) on egg production and yolk cholesterol levels in egg laying hens. Pakistan Journal of Nutrition, 16(7), 482-487. http://dx.doi.org/10.3923/pjn.2017.482.487

Dahiya, J. P., Wilkie, D. C., Van Kessel, A. G., \& Drew, M. D. (2006). Potential strategies for controlling necrotic enteritis in broiler chickens in post-antibiotic era. Animal Feed Science and Technology, 129(1-2), 60-88. https://doi.org/10.1016/j.anifeedsci.2005.12.003

Fadillah, I. Roni, SE, dkk. 2007. Sukses Beternak Ayam ras pedaging.

Fauziah, L. (2010). Isolation and identification of the Flavonoid compounds from the leaves of cassava (Manihotutilissiima Pohl).

Hardiyansyah. (2016). Journal. Effect of the giving of betel leaf flour (Piper Bettle L) as feed to meat broiler cholesterol. Makassar. Department of Livestock Sciences Faculty of Science and Technology UIN Alauddin Makassar, 2(3).

Haroen, U. (2003). Respon ayam broiler yang diberi tepung daun sengon (albizzia falcataria) dalam ransum terhadap pertumbuhan dan hasil karkas. J. Ilmiah Ilmu-ilmu Peternakan, 6(1), 34-41.

Haroen, U. (2014). Kajian ekstrak limbah jus jeruk sebagai feed additive dan pengaruhnya terhadap performa ayam broiler. Disertasi Pascasarjana Universitas Andalas. Padang.

Mardewi, N. K., Astiti, N. M. A. G. R., Rukmini, N. K. S., Rejeki, I. G. A. D. S., Tonga, Y., \& Suwitari, N. K. E. (2017). Supplementation of moringa (moringa oliefera) powder into ration in increasing the quality of broiler's meat. International Research Journal of Engineering, IT \& Scientific Research, 3(3), 31-44.

Rahayu, I. (2014). Principles of treatment. Husbandry Corner.

Reveny, J. (2011). Antimicrobial Activity of the Extract and Fraction of Red Betel Leaf (Piper betle Linn.). Jurnal Ilmu Dasar, 12(1), 6-12.

Sholikhah, A. (2006). Sirih Merah Menurunkan Glukosa Darah.

Sitepu, S. R. B., Herysupratman, Rd., \& Abun. (2002). The effect of energy balance and Protein ration against the digestibility of dry materials and coarse proteins in Broiler chickens. Faculty of Livestock. University of Padjajaran.

Suriani, N. L. (2018). Bioactive substance use of leaf extract of piper caninum blume pressing for blas disease and increase production in rice. International Journal of Life Sciences,2(2), 42-50. https://doi.org/10.29332/ijls.v2n2.156

Tillman, A., D.S. Reksohadiprojo., S. Prawirokusumo and S... (1991). Basic livestock Food Science. Gadjah Mada University Press. Yogyakarta.

Wibawa, A. A. P. P., Utami, I. A. P., \& Bidura, I. G. N. G. (2016). The effect of Garlic (Allium sativum) extract on performance, abdominal fat and serum cholesterol of broiler. Journal of Biological and Chemical Research, 33(2), 804-411. 


\section{Biography of Authors}

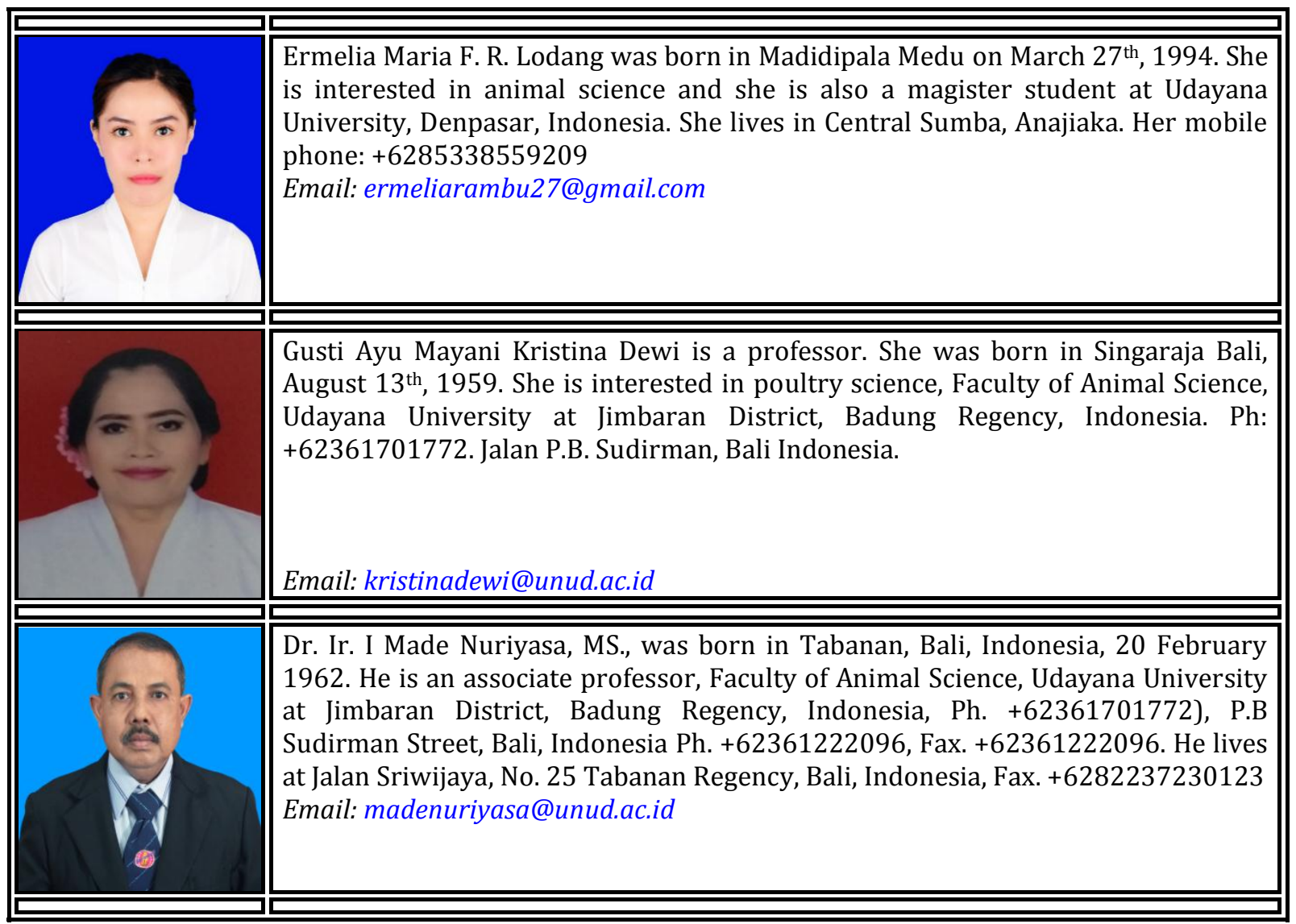

Lodang, E. M. F. R., Dewi, G. A. M. K., \& Nuriyasa, I. M. (2020). The effect of giving betel leaf extract (piper betel l.) on the production and quality of broiler carcasses. International Journal of Life Sciences, 4(1), 19-25. https://doi.org/10.29332/ijls.v4n1.373 